FACTA UNIVERSITATIS

Series: Physical Education and Sport, Vol. 17, No 2, 2019, pp. 289 - 298

https://doi.org/10.22190/FUPES190702027B

Research article

\title{
THE CORRELATION BETWEEN TIME MANAGEMENT AND STUDENT LEARNING OUTCOMES IN PHYSICAL EDUCATION
}

\author{
UDC 796:371.3:62-527
}

\author{
Jusuf Blegur ${ }^{1}$, M. Rambu P. Wasak ${ }^{1}$, Mieke Souisa ${ }^{2}$ \\ ${ }^{1}$ Faculty of Teacher Training and Education, Artha Wacana Christian University, Kupang, \\ Indonesia \\ ${ }^{2}$ Faculty of Teacher Training and Education, Pattimura University, Ambon, Indonesia
}

\begin{abstract}
This research was conducted with an aim to examine the relationship of time management with the physical education learning outcomes in high-school students of both genders, aged 17.60 \pm 0.89 (Mean $\pm S D$ ). The data of Time management from respondents were taken using the Time Management Questionnaire (Alay \& Kocak, 2002). Data on learning outcomes were taken from the learning value of Physical Education students in the first semester of the school year 2018/2019. The results of the descriptive test indicates that the time management of students was classified as fair (62.71\%) and their learning outcomes were also good $(83.05 \%)$, while the results of the Pearson test showed a significant relationship between time management with physical education learning outcomes (0.314) Thus, educators can train students to develop time management skills by arranging plans before doing, determining and setting work priorities, being responsible for work time and priorities, and avoiding unfavorable activities.
\end{abstract}

Key words: Time Management, Learning Outcomes, Academic Performance, Physical Education

\section{INTRODUCTION}

Learning outcomes are a representation of students' achievement of competencies that will be useful to enter the workforce (Wulandari \& Surjono, 2013), so that each student involved in learning activities expects to have good learning outcomes. Good learning outcomes are the manifestation of activeness, seriousness, and totality during learning. Learning outcomes seem easy when quantified, but the process of achieving them requires

Received July 02, 2019/ Accepted October 01, 2019

Corresponding author: Jusuf Blegur

Artha Wacana Christian Univeristy, Faculty of Teacher Training and Education, Kota Kupang, Adi Sucipto, 147, Indonesia

Phone: +62 380 881584• E-mail: jusufblegur@ukaw.ac.id 
complex struggles and activities from educators and students. Educators must be able to design learning processes that support student participation while students need motivation, discipline, and perseverance in learning, as well as critical and creative thinking. Decisions about student learning outcomes require a series of tests, assessment, and rigorous evaluations. As a result, learning outcomes can be said to be a reflection of a complex and competitive learning process (for each individual learner), as learning outcomes focus on students' cognitive, behavioral progress and students' progress that is measurable as they interact through learning activities (Keshavarz, 2011). Physical education differs from other forms of education by its particular characteristics. It is primarily aimed at health enhancement, development of physical skills, formation and improvement of motor skills, etc. All this is accomplished by means of particular activities - physical exercise (Maksimović \& Osmanović, 2018).

Time management is a series of practices assisting students get more value from time in order to improve their quality of life. However, students most often do not use their time wisely, as what is expected of them to achieve their goals (Adebayo, 2015). This condition often makes students confused when controlling a series of learning tasks and responsibilities. They tend to postpone work so that on the due date, they often do not submit it. Even if they are force to do the work, the results are not optimal. This is not solely because of limited knowledge or ability to think, but rather because of their incapability of controlling their study time. The practice of time management will have an impact on many things, as findings (Kayode \& Ayodele, 2015) indicate that an educator with good time management correlates with the academic performance of his students. Time management prioritizes activity priorities, so that secondary activities can be temporarily ignored. This is not an effort to avoid, but to rather selectively prioritize study or work so that all tasks and responsibilities can be maximally realized.

In this modern era, one of the most important problems for students is time management (Ocak \& Boyraz, 2016). A number of researchers have provided important notes about the time management process in every field of student life. Students, who are aware of the importance of time, are able to use it well and to compete with other students in every field of life. Opportunities for success can be increased by precisely controlling time effectively and efficiently (Khan, Farooqi, Khalil, \& Faisal, 2016). Time management not only establishes and achieves goals, but also helps participants achieve results in a very short time. Good time management functions more effectively and focuses on results. In addition, good time management is useful in several ways, including greater work productivity, reducing stress levels, increasing efficiency while working, more opportunities for professional improvement, and greater opportunities to achieve a career and life goals (Nayak, 2018). Time management skills are very important for completing all tasks on time. Students with good time management skills can be effective people in working or doing activities (Chansaengsee, 2017).

Students, who are able to plan their day and/or time well from the time they have, show real practice of time management (Gea, 2014). Time management is very important for everyone, especially for students (Mahasneh, Al-Zoubi, Batayneh, Al-Sawalmeh, \& Mahasneh, 2013). One key of the success of students is proper time management. Students need to manage their time effectively if they want to succeed (Nadinloyi, Hajloo, Garamaleki, \& Sadeghi, 2013). Being faced with various learning tasks from each educator, students must then use their time well. If they neglect to use their time, they may have poor academic 
performance. Students can reduce their academic anxiety and stress with good time management, because they need to overcome their tasks and personal achievements (Pehlivan, 2013; Nasrullah \& Khan, 2015). Good time management can increase academic motivation (Ghiasvand, Naderi, Tafreshi, Ahmadi, \& Hosseini, 2017), maintain work balance, increase work productivity, set and try to achieve goals (Alay \& Kocak, 2002), and more effective at work (Kholisa, 2012).

This research was conducted with an aim to examine the relationship of time management with the physical education learning outcomes of high-school students.

\section{METHODS}

\section{Respondents}

The total number of respondents i.e., high-school students involved is 59, consisting of 29 males and 30 females, aged 17.60 \pm 0.89 (Mean \pm SD). Respondents were taken using a proportional stratified random sampling technique, among Eighth Grade (A-F) students in Citra Bangsa Christian Junior High School, Kupang, East Nusa Tenggara, Indonesia.

\section{Procedure}

The approach used in this study is a quantitative design correlation to associate the time management abilities of students with their learning outcomes. Before the research instrument was duplicated, it was first translated into Indonesian to make it easier for the respondents to understand the intent and meaning of each statement contained in the questionnaire. After that, the questionnaire was distributed to respondents after getting permission from the school leader. During the process of filling out questionnaires, the educators and researchers were in the classroom to ensure responses from the respondents about the statements. The questionnaire was collected again after the respondents finished filling out the questionnaire.

\section{Data collection and analysis}

The data for time management was taken using the Time Management Questionnaire (TMQ) developed by Sema Alay and Settar Kocak in 2002. This questionnaire was constructed from three main indicators, including: 1) Time planning consisting of 16 items; 2) Time attitude consisting of 7 items; and 3) Time waster consisting of 4 items. There are eight negative statements from 27 TMQ items $(16,18,22,23,24,25,26,27)$ while the data for learning outcome was taken from the documentation of students' grades in Physical Education subjects in the first semester of the 2018/2019 academic year. The researchers used documentation data on learning outcomes because the time management process of the students did not occur instantly and partially, so that researchers viewed learning outcomes of physical education data in the first semester of the 2018/2019 academic year valid. Further, the analysis process uses Pearson's correlation. If the sig. value is (2-tailed) is smaller than 0.05 , then there is a positive and significant correlation between time management and student learning outcomes. 


\section{RESULTS}

Data from the research results are grouped into two stages: the first is a descriptive analysis process used to map the two research variables separately. Furthermore, the process of correlation analysis is carried out to test the relationship between the two research variables (time management and learning outcomes).

\section{Descriptive analysis}

Descriptive analysis is used to categorize time management and student learning outcomes. Each variable is categorized into five, namely very good, good, fair, poor, and very poor. The results of the interpretation of descriptive analysis of research variables (time management and learning outcomes) as in table 1.

Table 1 Description of time management and learning outcomes of the respondents

\begin{tabular}{|c|c|c|c|c|}
\hline \multicolumn{2}{|c|}{ Time management } & \multirow[t]{2}{*}{ Category } & \multicolumn{2}{|c|}{ Learning outcomes } \\
\hline $\mathrm{F}$ & $\%$ & & $\mathrm{~F}$ & $\%$ \\
\hline 0 & 0.00 & Very good & 7 & 11.86 \\
\hline 19 & 32.20 & Good & 49 & 83.05 \\
\hline 37 & 62.71 & Fair & 3 & 5.09 \\
\hline 3 & 5.09 & Poor & 0 & 0.00 \\
\hline 0 & 0.00 & Very poor & 0 & 0.00 \\
\hline 59 & 100.00 & Total & 59 & 100.00 \\
\hline
\end{tabular}

The data in table 1 explains that students have "fair" time management, with a percentage value of 62.71. As junior high school students, the data helped them a lot in undergoing their academic lives, because in that period they needed a lot of socialization with other students their age, so that their time management would still need to be trained and guided. In addition, in this period students are generally not yet strong in setting focus, formulating goals, and establishing priorities. They are still potentially contaminated with invasions of other social behaviors that can disrupt and even undermine the smooth running of their academic activities. Therefore, educators still need learning strategies that implicitly or explicitly train time management as long as they pass the transition period. The learning outcome data in this analysis has a "good" trend, so that it becomes the basic capital for students to develop themselves in a more productive direction. Self-learning outcomes are intervened by many variables, so that students must continue to maintain and strive for coherent learning activities with learning objectives while applying their learning priorities so that they are not easily tempted by other "pleasures" that can disrupt their academic reputation.

\section{Pearson's analysis}

After going through the descriptive analysis, the researchers conducted a correlation test to see the direction of the relationship between the two research variables. This test will provide evidence about the positive or negative direction of the relationship and whether it has significance or not. The results can be labeled as follows. 
Table 2 The result of the analysis of correlation

\begin{tabular}{llcc}
\hline & & $\begin{array}{c}\text { Time } \\
\text { management }\end{array}$ & $\begin{array}{c}\text { Learning } \\
\text { outcomes }\end{array}$ \\
\hline Time & Pearson correlation & 1 & $.314^{*}$ \\
management & Sig. (2-tailed) & 59 & .015 \\
& $\mathrm{~N}$ & 59 \\
\hline Learning & Pearson correlation & $.314^{*}$ & 1 \\
outcomes & Sig. (2-tailed) & .015 & \\
& $\mathrm{~N}$ & 59 & 59 \\
\hline
\end{tabular}

Table 2 explains that there is a positive and significant relationship between time management and student learning outcomes. This result is proven by the value of the $\mathrm{r}$ calculation (0.314) with a sig. value (2-tailed) which is smaller than $0.05(0.015)$. Thus, educators can train and develop students' time management skills to maximize their learning outcomes in physical education learning.

\section{DISCUSSION}

\section{Planning before doing}

Time management is very important, in fact it is able to affect the performance and overall achievement of individuals (Razali, Rusiman, Gan, \& Arbin, 2017). Time management talks about how one manages oneself (Nayak, 2018), both from the cognitive, emotional, social, and motor aspects. Even Nzewi, Chiekezie, \& Ikon (2016) recommend that effective time management skills should be taught to graduate students. Time management is not limited to time, but human domains that need to be controlled to be more productive. Students become successful in learning outcomes and are even able to fully develop for their activities are full of planning. They know what position they need to adopt in their life, because indeed all information received needs to be followed up simultaneously. Before students start their academic and non-academic activities, they first determine which "map" they need to traverse. This map is a guide for students to choose and sort out one of the various actions they will take, so that they are more effective in using their resources. Therefore, planning a good time is important for working with professionals to increase productivity and quality of life (Jackson, 2009). For instance Nayak said (2018) that time is free and invaluable, everyone has it, but how we use it is most important.

There are various alternatives for students to set their time, but the basis for each time management process is related to the planning process. Each student has a goal when studying, there is a need to prioritize work and make use of it every time (Farrell, 2017). If students are "limited and erroneous" filling their free time, it will have a negative impact on their growth and development (Blegur \& Wasak, 2017). Planning in management includes the determination and application of the most efficient methods to complete quality of assignments (Sahito, Khawaja, Panhwar, Siddiqui, \& Saeed, 2016). Planning is an effective management mechanism to assist students to stay on the "destination rail". Indeed, not everything can run smoothly, but through planning students easily identify work priorities and methods so that they help eliminate activities that are not profitable in achieving goals, 
including students who chose to study in comfortable facilities (Ajayi \& Yusuf, 2017) in order to improve their learning outcomes. Students can plan anything they want, such as choosing strategies and learning materials, which is a natural thing to do. Planning is not an effort to separate what the educators have planned, but rather a process of self-preparation to integrate the learning process that is in line with the achievement of learning objectives oriented toward self-development and student learning outcomes. Why is that? Because each student is responsible for the learning behavior he chooses (Farrell, 2017), thus students need planning before they start to facilitate the achievement of learning outcomes.

\section{Finding the best time to determine and set priorities}

Within 24 hours, not all time is appropriate for students to plan and even decide on the priorities of their learning activities. Students need to determine some time limits that are actually appropriate in formulating their work priorities. Why is it important? Because to produce brilliant ideas, students need the right time, in which the conditions of mind and feeling are truly matched. Small notes can be used by the students in order to ensure which important situations they need to prioritize during learning activities. For instance, group work time, time to submit assignments, time to correct tasks, and so forth. Particularly in demanding work situations, students must schedule well to maximize the process and the results of their work. According to Khatib (2014) and Chansaengsee (2017), good time management such as setting goals and priorities and monitoring the use of time can facilitate productivity and minimize stress, contribute to work effectiveness, maintain academic balance and success. In this sense, students have the potential to suffer from stress if they are productive and effective in their academic performance. For this reason, by setting priorities during work, it is easier to become successful.

There are differences in time management skills in terms of gender, age, education, work experience, and managerial experience (Ziapour, Khatony, Jafary, \& Kianipour, 2015) so that time management can be difficult for "A", and feel easy for "B". Some people think that time is difficult to control, and even their assumptions make it difficult to control their time, though time is very easy to control by starting to determine the needs and priorities of the task (Khan et al., 2016). Time management is a process of managing time according to the needs of the work by relying on activities to utilize, save, and not to waste time for progress and success (Sahito et al. 2016). Students may plan all their activities, but being able to commit and be consistent, to set and respect priorities is a critical thing that students must observe. Respecting priorities is a basic need, because there is no reason for students to succeed in learning if they do not respect the priority of work they have set themselves. Establishing and respecting work priorities helps students focus on their goals, facilitates preparation and increases the chances of achieving success. Students move more systematically to minimize stress levels with good time management because they work to deadlines (Khatib, 2014), in which they must complete assignments on time, have more free time for relaxing activities, and feel happier (Chansaengsee, 2017).

\section{Responsible for scheduled time}

The planned schedule and priority of work must be followed up immediately, because it is part of how students respect their work priorities. If this is not done (delayed), it will increase anxiety, and this is the main obstacle of time management (Jackson, 2009). At a 
more advanced level students make plans and determine their priority is having the courage to take responsibility for their plans. Students are able to do something, but they are not able to complete it before starting, because they do not have high responsibility. According to Kusumadewi, Sedanayasa, \& Antari (2014), responsibility is an awareness of behavior or actions. Students must be responsible for what they have scheduled, then the plans must answer their needs, such as their need to develop their knowledge and skills as well as their needs for achievement. In addition, by being responsible, students can complete learning expectations, whether the use of time, workload, or level of difficulty (Blegur, Manu, \& Souisa, 2018). The certainty of students in realizing responsibility must be evident in actions, for instance students start learning at 07.00 $08.00 \mathrm{pm}$ every day and/or have group study on Saturdays. Such actions refer to the personal leadership characteristics of students. This is what Farrell (2017) refers to as the link between time management and leadership. Students who have good leadership must have good time management, because they are able to lead themselves.

Time management can be synthesized from a variety of key elements, such as ensuring individuals fulfill their goals, effectively carrying out responsibilities, duties, and authority, helping people solve problems, helping to complete tasks on time, and building a balanced work life (Chansaengsee, 2017). Pickle Jar's theory also states that individual activities and responsibilities need to be balanced using an effective and efficient time management system. Time needs to be allocated to everything and things that are suitable (Nzewi et al., 2016) and productive, for instance work schedules with more advanced planning, organizing, and implementation (Sahito et al., 2016). Students must be responsible for everything they have initiated in planning, because it relates to activities that are relevant to achieving their goals. Responsibility means that students do not miss every aspect of their work, because they are aware that ignorance will trap them in a high volume of workload and ultimately lead to saturation and even withdrawal from a number of activities. Time management actually provides the opportunities for students to complete their workload in a simple, gradual, and balanced manner because they do not act hastily. Therefore, when students do not ignore one of the aspects of work, they are able to work responsibly and implicitly, they have worked on their time management, so that they can improve their time management skills (Nadinloyi et al., 2013).

\section{Avoiding unprofitable activities}

Students need to manage their time effectively if they want to succeed, because appropriate time management is one of the keys to success in education (Nadinloyi et al., 2013). Time management is also an important component for achieving high productivity (Farrell, 2017). There will be various activities that are not useful if students are not able to control their time. Activities that students are involved in during their school life or in their community life and family life should be based on activities that benefit them. Indeed, all important activities for students, particularly those who grow and develop in the transition period greatly require socialization through activities in the students' environment. Time management is closely related to academic performance (Miqdadi, ALMomani, Masharqa, \& Elmousel, 2014); therefore, students must ensure that they do not to engage in unfavorable activities. It could be that they "pull away" in elegant ways, i.e., "I will join after completing group assignments" or "I need to complete the study 
assignment, my apology I can't participate in this opportunity". Withdrawing from unfavorable activities must also be full of nuances of appreciation and understanding so as not to cause new problems due to their decision.

Students with good time management have a low reputation for academic procrastination (Ocak \& Boyraz, 2016), as they report a greater evaluation of their performance, greater work and life satisfaction, fewer role ambiguities, fewer excessive roles, and less workrelated and somatic tension (Macan, Shahani, Dipboye, \& Phillips, 1990). Students often experience procrastination due to poor time control, they are not critical in determining useful activities. In this case it is very important that they do not taken part in interactions and destructive social behavior, such as truancy, smoking, drunkenness, and so forth. Students only need to hone and develop things that become their potential by controlling their time well, so that they really succeed in their academic and psycho-social development. The scientific findings of Ghiasvand et al. (2017) revealed that time management skills are very important for the success and development of competencies, thus from the indicators of success, time management is one of the indicators that support students' personal development. Therefore, students need to train and develop the key to a successful time management, including setting goals that are realistic, be regular in their activities, and stop feeling guilty (Jackson, 2009).

\section{CONCLUSIONS}

The results of the research revealed that time management can help students maximize their learning outcomes. They can control learning activities well of which their activities are focused on things that are constructive for themselves. As high school students, there are many times and opportunities that can help them become positive or vice versa. For this reason, time management is an important part for students to determine the ultimate goal in their academic life, so that they do not fill learning opportunities with destructive activities. Learning outcomes are not something instant, even though the way to measure them tends to be instant. There are a number of activities that educators can use to assess learning outcomes, such as the readiness of students to look for answers or practices on instructions given, and the readiness of students to complete assignments briefly and with quality so that they must be ready anytime. Positive learning outcomes can be controlled through early planning, determining and setting of priorities for work, being responsible for the time and priority of work determined, and avoiding unfavorable activities. There are a number of people who feel difficulty in learning and even fail, but these conditions are not solely because of their poor cognitive structure, but rather the time management. Learning outcomes are not placed at the beginning but at the end of learning activities, so that students need to control their learning time early in order to pass and acquire quality of learning processes and learning outcomes. 


\section{REFERENCES}

Adebayo, F.A. (2015). Time management and students academic performance in higher institution, Nigeria-A case study of Ekiti State. International Research in Education, 3(2), 1-12.

Ajayi, I.A., \& Yusuf, M.A. (2017). School plants planning and students' learning outcomes in south west Nigerian secondary schools. International Journal of Educational Science, 2(1), 47-53.

Alay, S., \& Kocak, S. (2002). Validity and reliability of time management questionnaire. Hacettepe Universitesi Egitim Fakultesi Dergisi, 22, 9-13.

Blegur, J., \& Wasak, M.R.P. (2017). Permainan kecil: Teori dan aplikasi. Kupang: Jusuf Aryani Learning.

Blegur, J., Manu, T.S.N., \& Souisa, M. (2018). Students' disciplined character as the effort to improve selfesteem and academic performance. International Journal of Academic Research in Business and Social Sciences, 8(4), 366-376.

Chansaengsee, S. (2017). Time management for work-life and study-life balance. Verdian E-Journal, 10(5), 20-34.

Farrell, M. (2017). Leadership reflections. Journal of Library Administration, 57, 215-222.

Gea, A.A. (2014). Time management: Menggunakan waktu secara efektif dan efisien. Humaniora, 5(2), $777-$ 785 .

Ghiasvand, A.M., Naderi, M., Tafreshi, M.Z., Ahmadi, F., \& Hosseini, M. (2017). Relationship between time management skills and anxiety and academic motivation of nursing students in Tehran. Electronic Physician, 9(1), 3678-3684.

Jackson, V.P. (2009). Time management: A realistic approach. Journal of the American College of Radiology, 6(6), 434-436.

Kayode, G.M., \& Ayodele, J.B. (2015). Impact of teachers' time management on secondary school students' academic performance in Ekiti State, Nigeria. International Journal of Secondary Education, 3(1), 1-7.

Keshavarz, M. (2011). Measuring course learning outcome. Journal of Learning Design, 4(4), 1-9.

Khan, H.M.A., Farooqi, M.T.K., Khalil, A., \& Faisal, I. (2016). Exploring relationship of time management with teachers' performance. Bulletin of Education and Research, 38(2), 249-263.

Khatib, A.S.A. (2014). Time management and its relation to students' stress, gender and academic achievement among sample of students at Al Ain University of Science and Technology, UAE. International Journal of Business and Social Research, 4(5), 47-58.

Kholisa, N. (2012). Hubungan manajemen waktu dengan efektivitas kerja karyawan. Journal of Social and Industrial Psychology, 1(1), 56-60.

Kusumadewi, K.R., Sedanayasa, G., \& Antari, N.N.M. (2014). Efektivitas konseling Gestalt dengan teknik "saya bertanggung jawab atas...." Untuk meningkatkan tanggung jawab akademik siswa (The effectiveness of Gestalt counseling with the technique "I am responsible for ...." To increase students' academic responsibility). Jurnal Online Jurusan Bimbingan dan Konseling, 2(1), 1-12. In Indonesian

Macan, T, Shahani, C., Dipboye, R.L., \& Phillips, A.P. (1990). College students' time management: Correlations with academic performance and stress. Journal of Educational Psychology, 82, 760-768.

Mahasneh, A.M., Al-Zoubi, Z.H., Batayeneh, O.T., Al-Sawalmeh, A.A., \& Mahasneh, A.M. (2013). Attitudes university students towards time management skills. European Journal of Social Sciences, 38(3), 392-399.

Maksimović, J., \& Osmanović, J. (2018). Physical education teachers as reflective practitioners and action researchers in their work. Facta Universitatis Series Physical Education and Sport, 16(2), 375-386.

Miqdadi, F.Z., ALMomani, A.F., Masharqa, S., \& Elmousel, N.M. (2014). The relationship between time management and the academic performance of students from the petroleum institute in Abu Dhabi, the $U A E$. American Society for Engineering Education Zone I Conference (pp. 1-5), University of Bridgeport, CT, USA.

Nadinloyi, K.B., Hajloo, N., Garamaleki, N.S., \& Sadeghi, H. (2013). The study efficacy of time management training on increase academic time management of students. Procedia-Social and Behavioral Sciences, 84, 134-138.

Nasrullah, S., \& Khan, M.S. (2015). The impact of time management on students' academic achievement. Journal of Literature, Languages, and Linguistics, 11, 66-71.

Nayak, S.G. (2018). Time management in nursing-Hour of need. International Journal of Caring Science, 11(3), 1997-2000.

Nzewi, H.N., Chiekezie, O.M., \& Ikon, M.A. (2016). Time management and academic performance of postgraduate students in Nigerian Universities. Review of Public Administration \& Management, 1(2), 180-192. 
Ocak, G., \& Boyraz, S. (2016). Examination of the relation between academic procrastination and time management skills of undergraduate students in terms of some variables. Journal of Education and Training Studies, 4(5), 76-84.

Pehlivan, A. (2013). The effect of the time management skills of students taking a financian accounting course on their course-grades and grade point averages. International Journal of Bussiness and Social Science, 4(5), 196-203.

Razali, S. N. A. M., Rusiman, M. S., Gan, W. S., \& Arbin, N. (2017). The impact of time management on students' academic achievement. Journal of Physics, 995, 1-7.

Sahito, Z., Khawaja, M., Panhwar, U.M., Siddiqui, A., \& Saeed, H. (2016). Teacher time management and the performance students: A comparison of government and private schools of Hyderabad, Sindh, Pakistan. World Journal of Education, 6(6), 42-50.

Wulandari, B., \& Surjono, H.D. (2013). Pengaruh problem based learning terhadap hasil belajar ditinjau dari motivasi belajar PLC di SMK. Jurnal Pendidikan Vokasi, 3(2), 178-191.

Ziapour, A., Khatony, A., Jafary, F., \& Kianipour, N. (2015). Evaluation of time management behaviors and its related factors in the senior nurse managers, Kermanshah-Iran. Global Journal of Health Science, 7(2), 366-373.

\section{KORELACIJA IZMEĐU UPRAVLJANJA VREMENOM I ISHODA UČENJA UČENIKA U NASTAVI FIZIČKOG VASPITANJA}

Ovo istraživanje je sprovedeno sa ciljem da se ispita odnos upravljanja vremenom sa ishodima

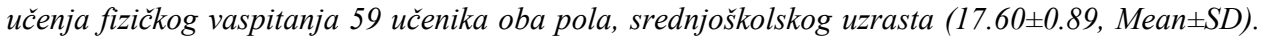
Podaci o upravljanju vremenom uzeti su od ispitanika korišćenjem Upitnika za upravljanje vremenom (Alaya \& Kocaka, 2002). Podaci o ishodima učenja dobijeni su od strane učenika u prvom polugodištu školske 2018/2019 godine. Deskriptivna statistika testa pokazuje da je upravljanje vremenom učenika klasifikovano kao dobro (62.71\%), kao i ishodi učenja (83.05\%), dok su rezultati Pearsonovog testa pokazali značajnu vezu između upravljanja vremenom i ishoda učenja fizičkog vaspitanja (0.314). Dakle, nastavnici mogu da sprovedu obuku razvijanja veštine upravljanja vremenom studenata organizovanjem planova pre sprovođenja samih programa nastave, određivanjem i utvrđivanjem prioriteta rada, odgovornošću u odnosu na radno vreme $i$ prioritete, te izbegavanjem neodgovarajućih aktivnosti.

Ključne reči: upravljanje vremenom, ishodi učenja, akademski učinak, fizičko vaspitanje 